\title{
CHANGES IN SOIL CARBON AND TOTAL NITROGEN FOLLOWING REFORESTATION OF PREVIOUSLY CULTIVATED LAND IN THE HIGHLANDS OF ETHIOPIA
}

\author{
Mulugeta Lemenih, ${ }^{1}$ Bekele Lemma ${ }^{1}$ and Demel Teketay ${ }^{2}$ \\ ${ }^{1}$ Wondo Genet College of Forestry, PO Box 128, Shashemene, Ethiopia \\ E-mail: elerohi@yahoo.com or wgcf@ethionet.et \\ 2 Ethiopia Agricultural Research Organization, PO Box 2003, Addis Ababa, Ethiopia
}

\begin{abstract}
Changes in soil $\mathrm{C}$ and total $\mathrm{N}$ stocks were investigated following reforestation of previously cultivated soil in compariso n with soil subjected to continuous cultivation and soil under an adjacent natural forests in south central highlands of Ethiopia. Two of the most widely planted tree species in the highlands of Ethiopia, namely Eucalyptus saligna and Cupressus lusitanica, were considered in the plantation treatments. Soil $C$ and total $\mathrm{N}$ contents in the upper 0-10 and $10-20 \mathrm{~cm}$ soil layers were significantly different in the order: Natural forest $>$ C. lusitanica $>$ E. saligna $>$ Farmland. Differences in soil $\mathrm{C}$ and total $\mathrm{N}$ contents among the sites for soil depths greater than $20 \mathrm{~cm}$ were negligibly small and statistically not significant. Soil $\mathrm{C}$ and total $\mathrm{N}$ stocks in the upper $0.80 \mathrm{~m}$ mineral soil also varied significantly in the same order as above. Estimated average annual soil C accruals were 156 and $37 \mathrm{~g} \mathrm{C}$ $\mathrm{m}^{-2} \mathrm{yr}^{-1}$ for Cupressus lusitanica and Eucalyptus saligna, respectively. The results demonstrate that reforestation of former arable soils in the dry Afromontane region of Ethiopia could yield significant restoration of soil $\mathrm{C}$ and total $\mathrm{N}$ that are lost in the process of natural forest conversion into arable lands and subsequent cultivation. However, the two plantation species differed considerably with respect to the rate of soil $\mathrm{C}$ and total $\mathrm{N}$ accrual. This suggests that proper selection of tree species will considerably affect the magnitude and rate of soil $\mathrm{C}$ sequestration.
\end{abstract}

\section{Key words/phrases: Continuous farming, Cupressus lusitanica, Eucalyptus saligna, soil carbon sequestration, soil carbon loss}

\section{INTRODUCTION}

Land degradation in the forms of soil erosion and declining soil fertility is threatening agricultural productivity, which is the mainstay of the economy, in Ethiopia. To achieve sustainable development on the basis of agricultural economy in Ethiopia, restoration of the vast degraded lands existing in the country is imperative. In fact, rehabilitation of degraded lands is a subject that is receiving considerable attention today in many parts of the world (Perrow and Davy, 2002), particularly in Sub Saharan Africa (SSA) (Chamshama and Nduwayezu, 2003). Reforestation or afforestation is one of the strategies proposed for rapid rehabilitation of degraded lands in the tropics (e.g., Parrotta et al., 1997; Lamb, 1998; Montagnini, 2001).

Moreover, reforestation or afforestation is one viable strategies propos ed for carbon sequestration to partially mitigate the elevated atmospheric $\mathrm{CO}_{2}$ (Winjum and Schroeder, 1997; Silver et al., 2000).
Although reforestation of arable lands offers substantial opportunity in $\mathrm{C}$ sequestration through fixation in biomass, the effect it makes on soil $\mathrm{C}$ is not yet clear (Malhi et al., 1999; Mendham et al., 2002). Research findings on changes in soil C following reforestation of previously arable lands have shown variable results ranging from large accumulation (e.g., Smith et al., 1997; Silver et al., 2000; Paul et al., 2003) to considerable reduction (e.g., Scott et al., 1999; Turner and Lambert, 2000). Because soil contains the largest terrestrial $\mathrm{C}$ stocks (Lal, 2001) as well as sequestration of $C$ in the soils is one of the main options identified for atmospheric $\mathrm{CO}_{2}$ mitigation (Smith et al., 1997), additional studies are needed to investigate the impacts of reforestation/-afforestation on soil C storage (Davis and Condron, 2002; Garten, 2002; Mendham et al., 2002).

In Ethiopia, reforestation activities have over a century of history. Today, plantation forests established for the purposes of supplying wood products and restoring degraded lands cover 
about 126,500 ha of lands in Ethiopia (Gebrekidan Teklu, 2003). According to the national inventory report by Gebrekidan Teklu (2003) few exotic species of the genera Eucalyptus (59.3\%) and Cupressus lusitanica (20.6\%) predominate the plantation forests in Ethiopia. Although such reforestation or afforestation programs provide opportunities to rehabilitate degraded soils (Fisher, 1995; Mulugeta Lemenih et al., 2004), no study has so far examined their potentials from soil fertility restoration, particularly from soil carbon sequestration viewpoint in Ethiopia. The objectives of this study were, therefore, to: (i) evaluate changes in soil $\mathrm{C}$ and total $\mathrm{N}$ contents/stocks following reforestation of previously cultivated soil; (ii) assess if soil $\mathrm{C}$ accumulation levels may differ between plantation species. Two of the most widely planted tree species in the highlands of Ethiopia, namely Eucalyptus saligna and Cupressus lusitanica were considered in the plantation treatments.

\section{MATERIALS AND METHODS}

\section{Study site}

The study was undertaken at Lepis, which is part of the Gambo district of the Shashamane Forest Industry Enterprise (SFIE). Lepis lies within latitudes $7^{\circ} 12^{\prime} \mathrm{N}$ and $7^{\circ} 14^{\prime} \mathrm{N}$, and longitudes $38^{\circ} 45^{\prime} \mathrm{E}$ and $38^{\circ} 47^{\prime} \mathrm{E}$ at about $240 \mathrm{~km}$ south of Addis Ababa (Fig.1). The study sites lie in the altitude range from 2100 to $2200 \mathrm{~m}$ a.s.l. The natural forest of Lepis is a dry Afromontane forest, and belongs to the Munessa-Shashamane-Forest that covers the eastern escarpment of the Central Ethiopian Rift Valley. The rainfall has bimodal distribution. The short rainy season extends between March and June and the major rainy season occurs between July and October. The mean annual rainfall is $1200 \mathrm{~mm}$ and annual mean temperature is about $20^{\circ} \mathrm{C}$. The soils of the area are classified as Mollic Andosol (FAO, 1998) or Humic Haplustands (Soil Survey Staff, 1999). The soils developed from volcanic parent materials, principally, volcanic lavas, ashes and pumices from quaternary volcanic activities in the Rift Valley. The soil texture in the surface layer of the soils of the study sites vary fom sand loam to loam with the compositions of $16-19 \%$ clay, $17-$ $36 \%$ silt and $54-66 \%$ sand.
The natural forest around Lepis suffered extensive deforestation for long period of time, a process that still continued unabated (Kebede Seifu, 1998). Pressure from increasing population and unplanned utilization of the forest has led to the shrinkage of the natural forest area, its composition and productivity leading to the modification of the forests through the introduction of plantation forestry (Anonymous, 1990). Considerable portion of the lower edge of the natural forest in Lepis was cleared in 1968 and converted to farmland. The forest was cleared with bulldozer and had been ploughed with tractor. Major crops cultivated in rotation are wheat, maize and barley. The farmland has been fertilized with mixture of diammonium phosphate (DAP) and Urea at the rate of $100 \mathrm{~kg} \mathrm{ha}^{-1} \mathrm{yr}^{-1}$ each beginning shortly after clearance and conversion of the site. Part of this farmland was abandoned after 16 years of continuous cultivation and reforested with different exotic tree species. Two plantation stands established on the abandoned farmland site used for this study were 17-years-old Eucalyptus saligna (hereafter referred to as Eucalyptus stand) and 15years-old Cupressus lusitanica (hereafter referred to as Cupressus stand). The Eucalyptus stand covers 25.5 ha with stem density and stand volume of 910 trees and $372.5 \mathrm{~m}^{-3} \mathrm{ha}^{-1}$, respectively. The Cupressus stand covers 5 ha with stem density and stand volume of 803 trees and $220 \mathrm{~m}^{-3} \mathrm{ha}^{-1}$ respectively. Mean annual increment $\left(\mathrm{m}^{3} \mathrm{ha}^{-1} \mathrm{yr}^{-1}\right)$ was 25.7 for the Eucalyptus stand and 18 for the Cupressus stand. All the sites were adjoining on the same topographic position, climate and soil type.

\section{Soil sampling and analysis}

Soil samples were collected from five pits arranged within $15 \mathrm{~m}$ radius of a central point established well inside each site. The pits were dug to $100 \mathrm{~cm}$ depth and soil samples were taken from $0-10,10-20,20-40,40-60$, and $60-80 \mathrm{~cm}$ increments from each pit with hand trowel uniformly along each sample depth. The soil samples were airdried, mixed well and passed through a $2 \mathrm{~mm}$ sieve for chemical analysis. Other sets of soil core samples from each pit and sample depth were taken for bulk density determination. A sharp edged steel cylinder (height $5 \mathrm{~cm}$ and diameter 7.2 $\mathrm{cm}$ ) was forced manually into the soil for drawing the samples for bulk density. 


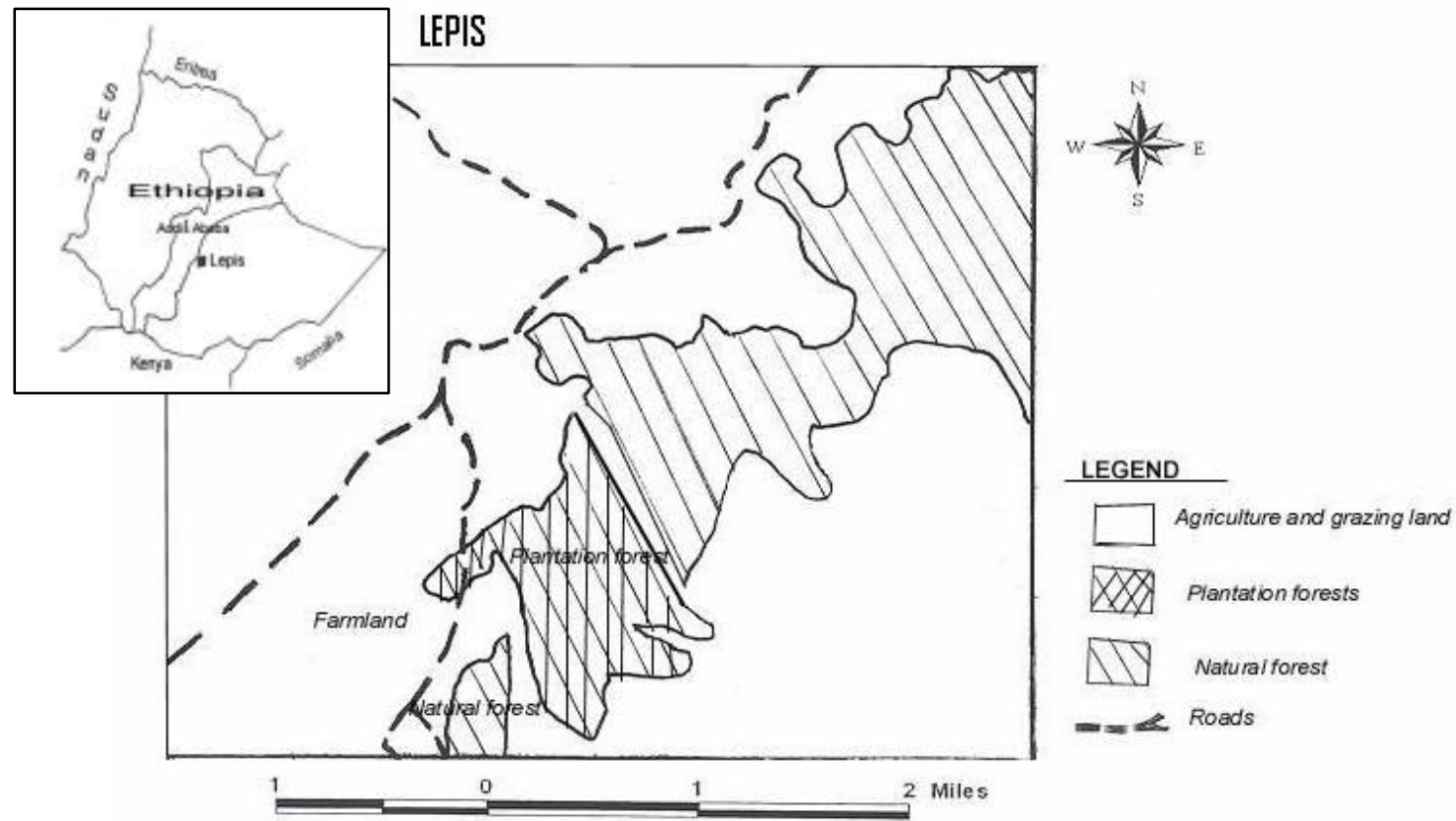

Fig. 1. Map of Lepis shows the natural forest, plantation stand and the farmlands from which samples were taken for the study.

Soil $\mathrm{pH}$ was measured in water and $1 \mathrm{M} \mathrm{KCl}$ suspension of 1:2.5 (soil: liquid ratio) using a glasscalomel combination electrode. Organic $\mathrm{C}$ and total $\mathrm{N}$ were analysed with a LECO-1000 CHN analyser and the results reported on oven-dry basis. As test with $\mathrm{HCl}$ in all the soil pits did not show signs of carbonate. Moreover, since all the soils had $\mathrm{pH}$ less than 7.0 (Table 1), we assumed that the total $\mathrm{C}$ obtained in the analysis closely estimates the organic $C$ contents of the soils. Bulk density $\left(\mathrm{g} \mathrm{cm}^{-3}\right)$ was determined after drying the core samples in an oven at $105^{\circ} \mathrm{C}$. Bulk density of each sample was calculated by dividing the total oven-dry mass of each sample by the volume of the soil core used in the sample collection. Bulk density was corrected for coarse fragment content after sieving crushed soil samples through a $2 \mathrm{~mm}$ sieve and weighing the soil fractions $<2 \mathrm{~mm}$ (mineral soil fraction) and $>2 \mathrm{~mm}$ (rock and ravel).

Table 1. Mean ( \pm SE) soil bulk density and soil $\mathrm{pH}$ in the upper 0-80 $\mathrm{cm}$ mineral soils under the natural forest (NF), Cupressus lusitanica (CL), Eucalyptus saligna (ES) and the farmland (FL).

\begin{tabular}{|c|c|c|c|c|c|}
\hline \multirow{2}{*}{ Soil property } & \multirow{2}{*}{ Depth (cm) } & \multicolumn{4}{|c|}{ Study sites } \\
\hline & & $\overline{\mathrm{NF}}$ & $\mathrm{CL}$ & ES & FL \\
\hline \multirow[t]{5}{*}{ Bulk density $\left(\mathrm{Mg} \mathrm{m}^{3}\right)$} & $0-10^{m+2}$ & $0.66(0.02)$ & $0.85(0.03)$ & $0.90(0.02)$ & $1.07(0.03)$ \\
\hline & $10-20^{\text {thent }}$ & $0.73(0.02)$ & $0.83(0.08)$ & $0.83(0.06)$ & $1.11(0.03)$ \\
\hline & $20-40^{*}$ & $0.99(0.05)$ & $0.89(0.03)$ & $0.98(0.04)$ & $1.07(0.04)$ \\
\hline & $40-60^{\text {rs }}$ & $1.09(0.03)$ & $0.91(0.07)$ & $1.01(0.06)$ & $1.06(0.04)$ \\
\hline & $60-80^{\text {ns }}$ & $0.94(0.05)$ & $0.85(0.06)$ & $0.91(0.05)$ & $0.98(0.06)$ \\
\hline \multirow[t]{5}{*}{$\mathrm{pH}$} & $0-10^{\text {stik }}$ & $6.20(0.19)$ & $6.23(0.15)$ & $5.42(0.07)$ & $6.51(0.07)$ \\
\hline & $10-20^{* *}$ & 6.05(0.09) & $6.50(0.15)$ & 6.07(0.29) & $5.48(0.08)$ \\
\hline & $20-40^{\text {ns }}$ & $6.16(0.04)$ & $5.87(0.09)$ & $5.69(0.03)$ & $6.69(0.10)$ \\
\hline & $40-60^{\text {ns }}$ & $6.46(0.06)$ & $5.55(0.09)$ & 6.11(0.04) & 6.58(0.01) \\
\hline & $60-80^{\text {ns }}$ & $6.11(0.10)$ & $5.15(0.12)$ & $5.47(0.02)$ & $6.22(0.03)$ \\
\hline \multirow{5}{*}{$\mathrm{C}: \mathrm{N}$ ratios } & $0-10^{* * *}$ & 9.1(0.29)a & $10.7(0.37) b$ & $11.4(0.30) \mathrm{c}$ & $10.7(0.13) \mathrm{b}$ \\
\hline & 10-20ns & 9.7(1.85) & $10.2(0.45)$ & $10.3(0.39)$ & $10.5(0.28)$ \\
\hline & 20-40ns & $11.3(0.52)$ & $10.2(0.84)$ & $10.0(0.11)$ & $10.5(0.38)$ \\
\hline & $40-60 \mathrm{~ns}$ & $10.3(0.12)$ & $7.9(0.0 .9)$ & $9.0(0.27)$ & $8.2(0.51)$ \\
\hline & 60-80ns & $8.7(0.22)$ & $6.5(0.31)$ & $7.2(0.41)$ & 7.1(0.13) \\
\hline
\end{tabular}

${ }^{* * * *}$ significantly different at $P<0.001,{ }^{* *} P<0.01,{ }^{*} P<0.05$; ns denotes not significantly difference at $P<0.05$. 


\section{Data analysis}

Soil C $\left(\mathrm{g} \mathrm{m}^{-2}\right)$ stock for each sampled depth was calculated using the following equation:

$$
C=\left(z \rho_{b} c\right) 10
$$

where,

$\mathrm{C}=$ carbon stock $\left(\mathrm{g} \mathrm{m}^{-2}\right)$ of a sample depth

$\mathrm{z}=$ thickness of a sample depth $(\mathrm{cm})$,

$\mathrm{p}_{\mathrm{b}}=$ bulk density $\left(\mathrm{g} \mathrm{cm}^{-3}\right)$ of a sample depth, and

$c=$ carbon content $\left(\mathrm{g} \mathrm{kg}^{-1}\right.$ soil) of a sample depth.

Total $\mathrm{N}\left(\mathrm{g} \mathrm{N} \mathrm{m}^{2}\right)$ stock for each sampled depth was also computed with a similar equation. Cumulative soil $\mathrm{C}$ and total $\mathrm{N}$ stocks to $0.80 \mathrm{~m}$ mineral soil were calculated by adding the soil $\mathrm{C}$ or total $\mathrm{N}$ stocks of the $0-10,10-20,20-40,40-60,60$ $80 \mathrm{~cm}$ soil increments, respectively.

Differences in soil bulk densities between land uses/land covers affect comparisons of soil organic carbon (SOC) stocks by influencing the amount of soils that are sampled from a fixed soil depth (Dawit Solomon et al., 2002; Mendham et al., 2002). Such differences in soil bulk densities between the natural forest, the plantations and the farmland in the preset study (Table 1) were accounted for by adjusting thickness of each sampled layer under each land use/land cover with respect to equivalent weights of soils under the natural forest using the equation:

$$
z_{\text {corr }}=\frac{\rho_{\text {forest }}}{\rho_{L U}} Z
$$

where,

$\mathrm{Z}_{\text {corr }}=$ adjusted thickness of a sample soil layers under plantation or farmland,

? forest $=$ bulk density of the sampled soil layer under the natural forest,

$?_{\mathrm{LU}}=$ bulk density of the sampled soil layers under plantation or farmland,

$\mathrm{z}=$ thickness of soil layers used during field sampling (Dawit Solomon et al., 2002).

The average annual accrual (rates of accumulation) of soil $\mathrm{C}$ and total $\mathrm{N}$ under the plantations were calculated after dividing the difference in soil C or total $\mathrm{N}$ stocks $\left(\mathrm{g} \mathrm{m}^{2}\right)$ in the soils of the plantations and the farmland by the age of the respective plantation. Similarly, average annual soil $\mathrm{C}$ and total $\mathrm{N}$ losses due to deforestation and subsequent cultivation were estimated after diving the difference in the total stocks $\left(\mathrm{g} \mathrm{m}^{-2}\right)$ of soil $\mathrm{C}$ and total $\mathrm{N}$ obtained under the natural forest and farmland by the age of the farmland since clearance and conversion. The soil analytical data were also subjected to one-way Analysis of variance (ANOVA) for each depth separately to observe whether or not the changes between soil $\mathrm{C}$ and total $\mathrm{N}$ of the soils of the plantations, the farmland and the natural forest were significant. Least significant difference (LSD) was used for mean separation for those properties that were found significantly different. The level of significance used was 0.05 .

\section{RESULTS}

\section{Soil $C$ and total $N$ contents and vertical distribution}

The soil $\mathrm{C}\left(\mathrm{g} \mathrm{kg}^{-1}\right)$ and total $\mathrm{N}\left(\mathrm{g} \mathrm{kg}^{-1}\right)$ contents in the $0-10$ and $10-20 \mathrm{~cm}$ soil layers under the natural forest, the plantation stands and on the farmland showed significant differences $(P<0.001)$. The soil of the natural forest had the highest significant soil C (79.7g kg-1) and total $\mathrm{N}\left(8.8 \mathrm{~g} \mathrm{~kg}^{-1}\right)$ contents followed by Cupressus stand in the $0-10 \mathrm{~cm}$ soil layer. In the same soil layer, the farmland had the lowest soil C $\left(32.6 \mathrm{~g} \mathrm{~kg}^{-1}\right)$ and total $\mathrm{N}\left(2.8 \mathrm{~g} \mathrm{~kg}^{-1}\right)$ contents. Compared with the soil of the farmland, the soils under Cupressus and Eucalyptus stands contained 30.52 and $7.99 \mathrm{~g} \mathrm{~kg}^{-1}$ higher soil C contents in the surface $0-10 \mathrm{~cm}$ soil layer.

In the 10-20 cm soil layer as well the soil of the natural forest had the highest significant soil $\mathrm{C}$ and total $\mathrm{N}$ contents. On the other hand, the differences in soil C and total $\mathrm{N}$ contents of the $10-20 \mathrm{~cm}$ layer between the Cupressus stand, Eucalyptus stand and the farmland were not statistically significant $(P>$ $0.05)$. However, soil $C$ contents were 3.50 and 0.68 $\mathrm{g} \mathrm{kg}^{-1}$ higher in the soils under Cupressus and Eucalyptus stands respectively that the soil of the farmland. Differences in soil C and N contents of below $20 \mathrm{~cm}$ soil depth were not statistically significant among all the sites. Generally, the vertical profiles in soil $\mathrm{C}$ and total $\mathrm{N}$ contents showed that differences were mostly confined to the upper 0-10 and 10-20 cm soil layers (Fig. 2). 

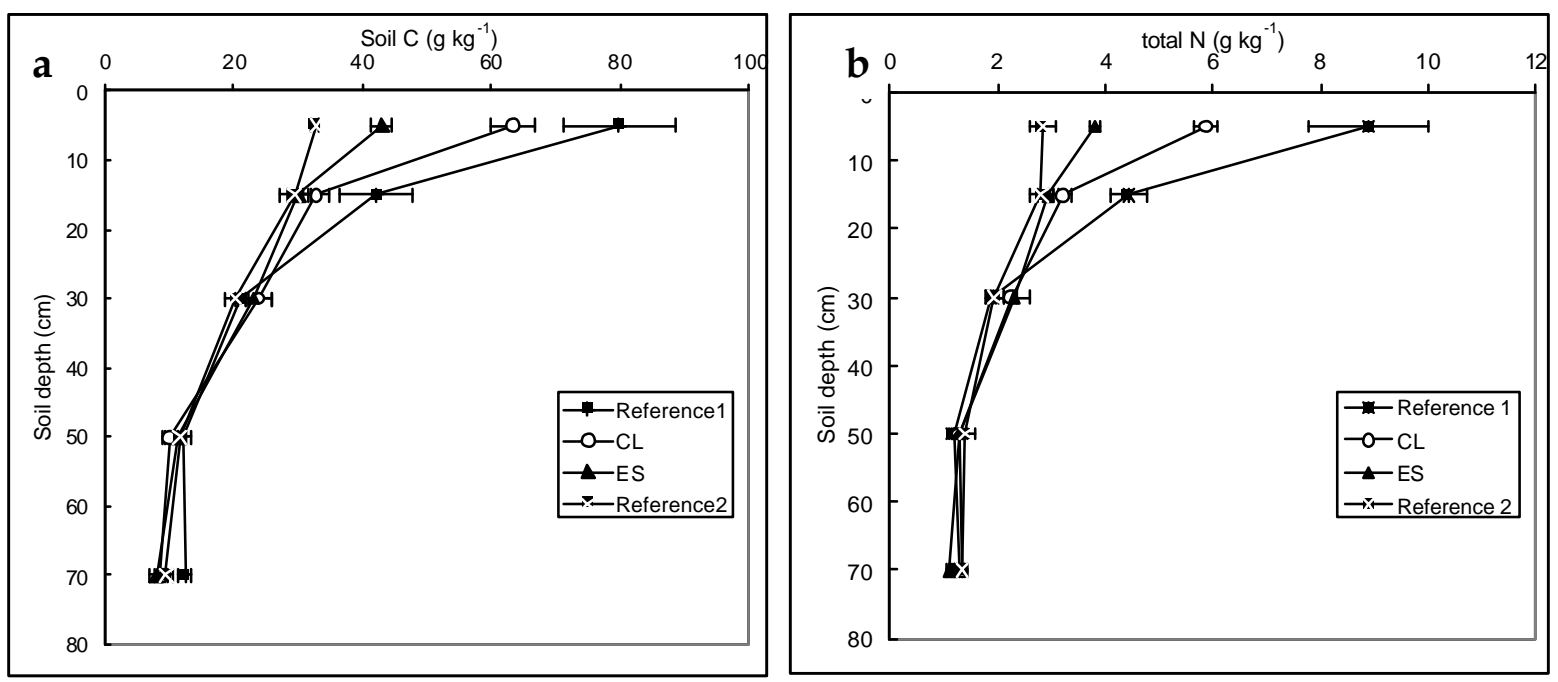

Fig. 2. Vertical profiles of mean $( \pm \mathrm{SE})$ of soil $\mathrm{C}(\mathrm{a})$ and total $\mathbf{N}(\mathrm{b})$ in $\mathbf{k g}^{-1}$ in the upper $0.80 \mathrm{~m}$ mineral soil Cupressus lusitanica (CL) and Eucalyptus saligna (ES) compared to the soil under adjacent natural forest (Reference 1) and farmland (Reference 2).

\section{C: $N$ ratios}

The C: $\mathrm{N}$ ratios of the surface $0-10 \mathrm{~cm}$ soil differed significantly $(P<0.001)$ among the natural forest, the plantations and the farmland (Table 1). The soil under the Eucalyptus stand had the highest C: $N$ ratio (11.36), while the soil of the natural forest had the lowest (9.05). There was no statistically significant difference in the $\mathrm{C}: \mathrm{N}$ ratios between the Cupressus stand and the farmland, while both of them had C: $\mathrm{N}$ ratios that were significantly higher than the natural forest and significantly lower than the Eucalyptus stand. The differences in C: $\mathrm{N}$ ratios of soil depths below 10 $\mathrm{cm}$ were not statistically significant between the four sites (Table 1).
Total soil $\mathrm{C}$ and $\mathrm{N}$ stocks in the upper $0.80 \mathrm{~m}$ soil layer

Soil C stocks $\left(\mathrm{g} \mathrm{m}^{-2}\right)$ in the upper $0.80 \mathrm{~m}$ mineral soil varied significantly $(P<0.001)$ among the natural forest, the plantation stands and the farmland. The minimum and maximum soil $\mathrm{C}$ stocks were $12,601 \pm 873$ and $17,826 \pm 1167 \mathrm{~g} \mathrm{~m}^{-2}$ in the farmland and natural forest, respectively (Fig. 3). While the soil $\mathrm{C}$ stocks in the natural forest was significantly higher than the other sites, the soil C stock in the Cupressus stand $\left(14943 \pm 475 \mathrm{~g} \mathrm{~m}^{-2}\right)$ was the second highest and was significantly higher than the soil $\mathrm{C}$ stock in the farmland. The Eucalyptus stand had a total soil C stock of $13238 \pm 868 \mathrm{~g} \mathrm{~m}^{2}$, which was slightly higher than the farmland, but the difference between the two was not statistically significant.
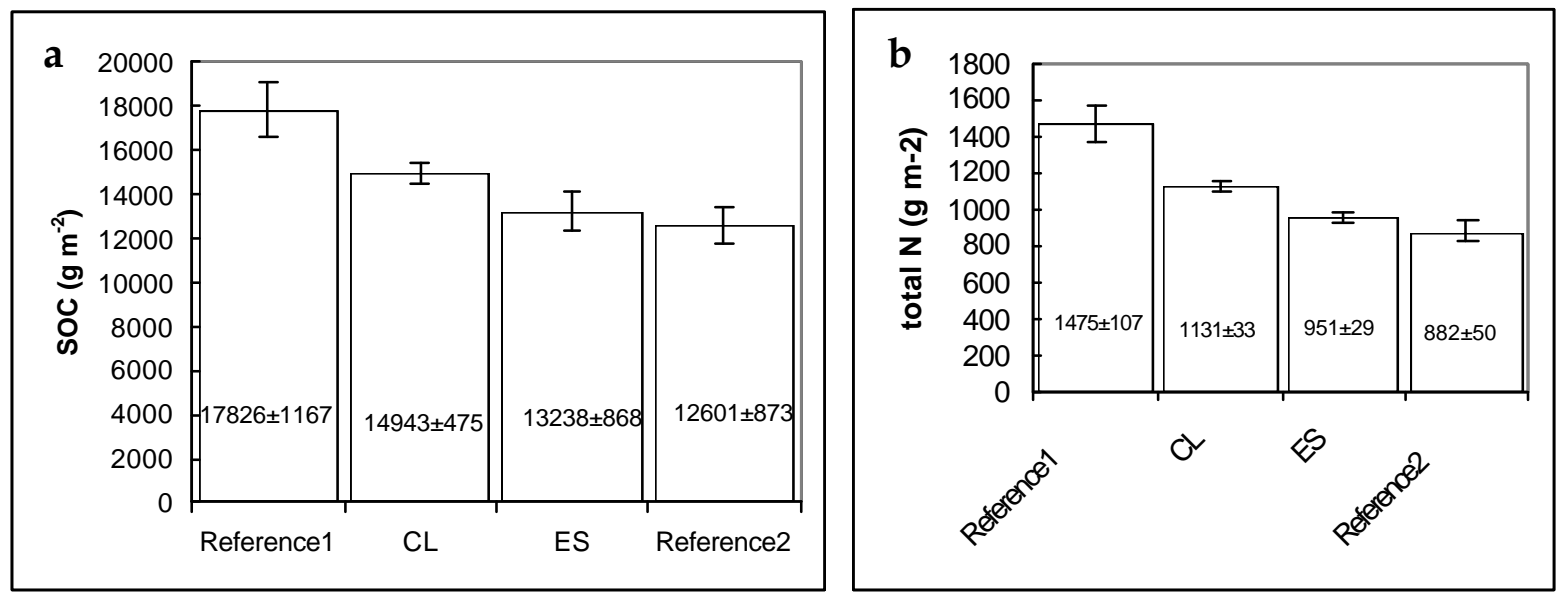

Fig. 3. Mean ( $\pm \mathrm{SE})$ soil $\mathrm{C}(\mathrm{a})$ and total $\mathrm{N}$ (b) stocks in $\mathrm{g} \mathrm{m}^{-2}$ in the upper $0.80 \mathrm{~m}$ mineral soil under Cupressus lusitanica (CL) and Eucalyptus saligna (ES) compared to the soils under adjacent natural forest (Reference1) and farmland (Reference2). 
The soil total $\mathrm{N}$ stocks $\left(\mathrm{g} \mathrm{m}^{-2}\right)$ in the upper $0.80 \mathrm{~m}$ mineral soil differed significantly $(P<0.001)$ among the sites. The natural forest, with total $\mathrm{N}$ stock of $1,475 \pm 107 \mathrm{~g} \mathrm{~m}^{-2}$ had the highest significant total $\mathrm{N}$ stock followed by the Cupressus stand with $1131 \pm 33 \mathrm{~g} \mathrm{~m}^{2}$ total $\mathrm{N}$ stock. The total $\mathrm{N}$ stocks in the soils of the Eucalyptus stand and the farmland were $951 \pm 29$ and $882 \pm 50 \mathrm{~g} \mathrm{~m}^{-2}$ respectively, and the difference between the two was not statistically significant.

\section{Loss of soil $C$ and total $N$ due to conversion of natural forest to arable land}

The soil $\mathrm{C}$ and total $\mathrm{N}$ stocks were significantly lower in the farmland compared with the soil under the natural forest. The loss of soil $\mathrm{C}$ from the upper $0.80 \mathrm{~m}$ mineral layer was found to be $5,225 \mathrm{~g}$ $\mathrm{m}^{-2}$ within 33 years of continuous cultivation after conversion from natural forest. This was $30 \%$ of the soil $\mathrm{C}$ stock in the natural forest soil. The average rate of soil $\mathrm{C}$ loss due to deforestation and subsequent cultivation is estimated to be $158 \mathrm{~g} \mathrm{~m}^{-2}$ $\mathrm{yr}^{-1}$. Similarly, $590 \mathrm{~g} \mathrm{~m}^{-2}$ or $40 \%$ of the soil total N stock in the natural forest was lost from the upper $0.80 \mathrm{~m}$ mineral soil of the farmland within 33 years of continuous cultivation after deforestation and conversion. This loss is at an approximate average rate of $17 \mathrm{~g} \mathrm{~m}^{-2} \mathrm{yr}^{-1}$ of total $\mathrm{N}$. Soil C and $\mathrm{N}$ losses occurred mainly in the upper $0-10$ and $10-20 \mathrm{~cm}$ soil layers, estimated at about $59.1 \%$ and $31 \%$, respectively. Similarly, $67 \%$ and $21 \%$ losses of total

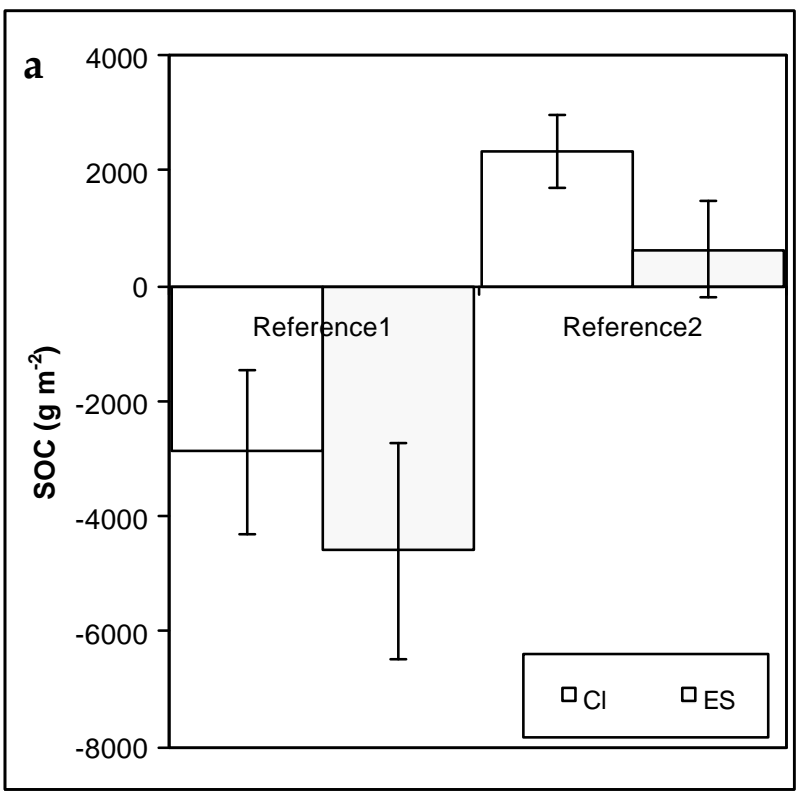

$\mathrm{N}$ took place in the $0-10 \mathrm{~cm}$ and $10-20 \mathrm{~cm}$ soil layers, respectively.

\section{Accumulation of soil $C$ and total $N$ following reforestation}

Reforestations of former farmland showed positive changes in soil $\mathrm{C}$ and total $\mathrm{N}$ with respect to the soils of the adjacent farmland (Fig. 4). Soil C was higher by 2342 and $637 \mathrm{~g} \mathrm{~m}^{-2}$ in the soils under Cupressus and Eucalyptus stands, respectively than the soil of the farmland. The average annual soil C accumulations in the plantation stands were estimated to be in the order of 156 and $37 \mathrm{~g} \mathrm{~m}^{-2} \mathrm{yr}^{-1}$ for the Cupressus and the Eucalyptus stands, respectively. Similarly, there was $250 \mathrm{~g} \mathrm{~m}^{-2}$ and 69 $\mathrm{g} \mathrm{m}^{2}$ higher total $\mathrm{N}$ in the soils of the Cupressus and the Eucalyptus stands, respectively, compared with the soil total $\mathrm{N}$ stock in the farmland (Fig. 4).

Like the losses in soil $\mathrm{C}$ and total $\mathrm{N}$ following conversion of natural forest into arable land, soil C and total $\mathrm{N}$ gains were clearly most pronounced in the upper $0-10$ and $10-20 \mathrm{~cm}$ soil layers. About $81 \%$ gains in the Cupressus stand and $71 \%$ gains in the Eucalyptus stand were in the surface $0-10 \mathrm{~cm}$ soil layer. Despite the clear changes in soil C following reforestation of former agricultural lands, however, after 15-17 years of stand development the soil $\mathrm{C}$ and total $\mathrm{N}$ stocks under the plantations are still far lower than the soil $\mathrm{C}$ and total $\mathrm{N}$ stocks in the soil of the adjacent natural forest (Fig. 4).

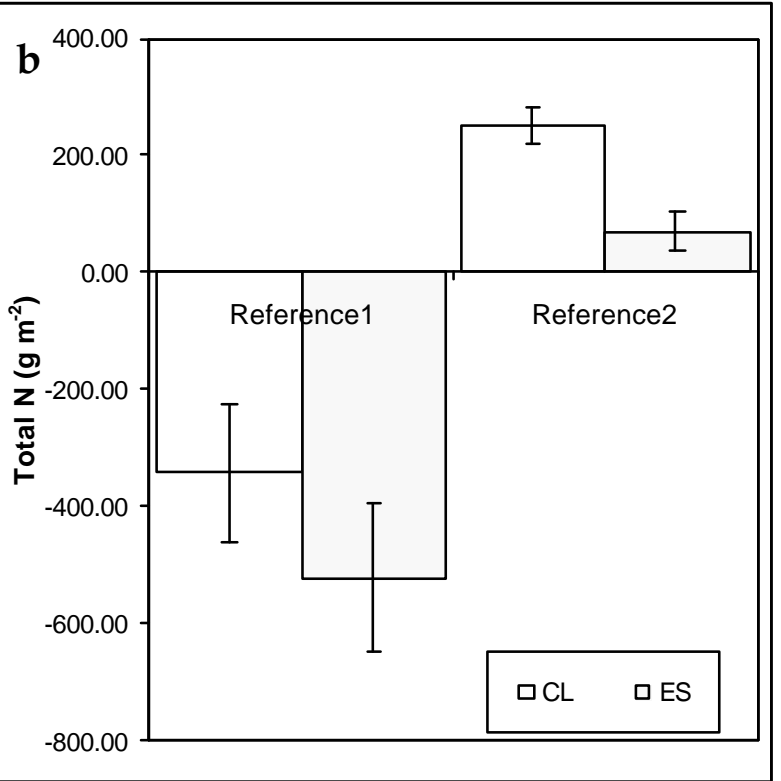

Fig. 4. Mean (( \pm SE) changes in soil C (a) and total $\mathbf{N}(\mathrm{b})$ in the $0.80 \mathrm{~m}$ mineral soil under Cupressus lusitanica (CL) and Eucalyptus saligna (ES) plantations with reference to the soils under adjacent natural forest (Reference1) and farmland (Reference2). 


\section{DISCUSSION}

The results of this study showed that conversion of Afromontane natural forest into arable land causes a considerable decline in soil $\mathrm{C}$ and total $\mathrm{N}$ stocks. This is consistent with findings of several studies (e.g., Sombroek et al., 1993; Teissen et al., 1994; Mulugeta Lemenih and Fisseha Itanna, 2004) concerning the declines in soil $\mathrm{C}$ and total $\mathrm{N}$ following the conversion of native vegetation into agricultural system, particularly crop production in the tropics. The underlying reason primarily is soil tillage, which enhances aeration and breakdown soil aggregates to allow physical contact of soil organic matter to decomposer organisms (e.g., Balesdeent et al., 1988; Dawit Solomon et al., 2002). In addition, soil $\mathrm{C}$ losses following deforestation and subsequent cultivation is exacerbated particularly in the case of tropical small-holder farmers such as those from the highlands of Ethiopia where crop residues form important parts of the harvest and are removed from the farm fields (Dawit Solomon et al., 2002; Mulugeta Lemenih and Fisseha Itanna, 2004). Nonetheless, the present study showed that reforestation of former farmlands will reverse soil $\mathrm{C}$ stocks by sequestering carbon in the soil. This is also consistent with several studies that indicated increased sequestration of soil $\mathrm{C}$ following conversion of former agricultural lands to perennial vegetation through reforestation or afforestation (..g., Polglase et al., 2000; Post and Kwon, 2000; Silver et al., 2000; Garten, 2002). The average rates of soil $C$ accrued by the plantations in the current study are within the ranges of reported soil $\mathrm{C}$ accumulation following reforestation and afforestation from other similar studies (e.g., Post and Kwon, 2000; Polglase et al., 2000; Silver et al., 2000; Garten, 2002; Paul et al., 2002). The average accumulation rate of soil $\mathrm{C}$ for the Cupressus lusitanica stand was greater than the weighted average change in soil $C$ of several afforested former arable lands reviewed by Paul et al. (2002).

The changes in soil $C$ under the plantation stands compared to the farmland soil could be attributed to (i) higher inputs of organic substrates from the plantation than from the cropping system, and (ii) reduced decomposition of both newly added and the old soil $\mathrm{C}$ owing to the minimum soil disturbances in the plantations than the farmlands. Nevertheless, the soil C and total $\mathrm{N}$ stocks under the plantations are still far lower than the soil $\mathrm{C}$ and total $\mathrm{N}$ stocks of the soil of the adjacent natural forest. This means that 15-17 years may not be long enough for the plantation stands to offset the soil $\mathrm{C}$ and total $\mathrm{N}$ lost due to deforestation and cultivation in the area. In fact, time since reforestation/afforestation has a significant effect on accumulation in soil C (Trouve et al., 1994; Paul et al., 2002; 2003). Soil C accumulation at early stages of plantation development (<10 years) could be either low or negative as there is relatively little input of $\mathrm{C}$ from aboveground biomass due to a small forest biomass and low rate of little fall. However, this trend gradually improves as the plantation matures and accumulation continues relative to the plantation ages (Trouve et al., 1994; Post and Kwon, 2000; Paul et al., 2002; 2003), provided other factors remain constant. For instance, after reviewing several reports on soil C accumulation following reforestation or afforestation Paul et al. (2002) showed that soil C decreases in young $(<10$-year) forest stands, but accumulation is maximized if forest rotation is maintained for 20-50 years. This may suggest that the relatively young age since the establishment of the plantation stands studied can explain for the shortfall to completely offset the soil C and total N lost due to cultivation. Assuming the same average rate of annual soil $\mathrm{C}$ accumulation, the time taken for the plantations to achieve equivalent amount of soil $\mathrm{C}$ stock $(0.80 \mathrm{~m})$ as in the adjacent natural forest was estimated to be 18 years for Cupressus lusitanica and 124 years for Eucalyptus saligna. However, Post and Kwon (2000) acknowledged uncertainties in estimating rates of soil $\mathrm{C}$ accrual that arise from long averaging times (typically several decades) because of the potential nonlinear dynamics in soil $\mathrm{C}$ accumulation under perennial vegetation.

On the other hand, the study showed considerable difference between the two plantation species with respect to their potential in soil C accrual. This confirms several other studies where significant effects of forest type (species) on soil C have been reported (e.g., Lugo, 1990; Paul et al., 2002). The soil under Cupressus lusitanica had 13\% soil C and $19 \%$ total $\mathrm{N}$ greater accumulations in the whole $0.80 \mathrm{~m}$ soil depth than the soil of Eucalyptus saligna species despite the 2 year earlier establishment of the later species. This may be related to several aspects of species-specific factors such as 
litter fall, root dynamics, and rate of transfer of $C$ from litter to soil (i.e. litter quality and humification rate) (Parrotta, 1999; Jobbagy and Jackson, 2000; Berg, 2001; Mendham et al., 2002; Paul et al., 2002). It appeared that compared to Cupressus lusitanica, the Eucalyptus stand produced lower litter that decomposes slowly leading to low soil $\mathrm{C}$ accumulation. This was consistent with several studies that have shown low litter production and slow decomposability in Eucalyptus stands compared to several other species (2.g., Bernhard-Reversat, 1987; Jonsson et al., 1996), but inconsistent with the review report by Paul et al. (2002). For instance, Jonsson et al. (1996) reported a little contribution to soil C from the litters of Eucalyptus spp. compared b several other species in Tanzania. Bernhard-Reversat (1987) has reported Eucalyptus litter to have high levels of soluble components, lower microbial respiratory outputs and low amount of organiclight fraction, which consequently leads to degraded soil organic matter beneath Eucalyptus plantations. Other studies have also reported a less favourable condition for litter decomposition under Eucalyptus plantations because of generally low moisture contents in soil under Eucalyptus (Grove et al., 2001), reduced number and diversity of soil fauna (e.g., earthworm numbers) (Kardell et al., 1986; Hingston et al., 1989; Bi et al., 1992), and anti-microbial effects (Della Bruna et al., 1991), which all together may contribute to lower soil C stock under this species.

Based on the results from this study, the area needed for reforestation to offset the national $\mathrm{CO}_{2}$ emissions, which is estimated to be $16,297 \mathrm{Gg} \mathrm{CO}_{2}$ (Asress Wolde Giorgis, 1995), by sequestering as soil $\mathrm{C}$ was estimated to be 9.7 million hectares (equivalent to $7.4 \%$ of the country's landmass) assuming 75\% Eucalyptus and 25\% Cupressus species plantations. If Cupressus species alone is considered, because of its superior soil C sequestration as shown in this study, as little as 2.8 million hectares (equivalent to $2.1 \%$ of the country's landmass) is required. Since large quantities of $C$ are also stored in the root, litter and above ground biomass, in effect a much less area of land will be needed to offset the national $\mathrm{CO}_{2}$ emissions in Ethiopia. These estimated areas are comparatively little compared to the vast degraded landmass available in the highlands of Ethiopia today.

\section{CONCLUSION}

The results of this study showed that reforestation/afforestation can be used to restore soil $\mathrm{C}$ and total $\mathrm{N}$, and thus soil productivity in the highlands of Ethiopia. In addition, reforestation can be used as a strategy to offset the national $\mathrm{CO}_{2}$ emission to comply to the international convention on climate change for which the country is one of the signatories. On the other hand, the large difference in soil $C$ accrual rate between the tree species considered strongly suggests the need for proper species selection in reforestation or afforestation programs designed for C sequestration or degraded land restoration. Furthermore, the soil $C$ accumulation rates in the plantations, without accounting for the $\mathrm{C}$ stored in the biomass, were found to be lower than the rate of soil C loss when natural forest is converted to agricultural land use. This is probably due to either (i) the large soil $\mathrm{C}$ loss from the agro-ecosystems owing to the poor soil managements and/or (ii) due to factors related to the plantation management most probably to the ages of the plantations.

\section{ACKNOWLEDGEMENTS}

We would like to acknowledge the support received from Atsmachew Bizuwork who has been with us during the whole period of the fieldwork. We also would like to thank Shawal Betru, Taye Gidyelew, Bezashwork Melaku and all staff members of the Munessa-Shashamane Forest Industry Enterprise for their assistance during the field data collection as well as laboratory sample preparations.

\section{REFERENCES}

1. Anonymous (1990). Munessa-Shashamane State Forest Project Management Plan. Forest management division /SFCDD/NRCDM/MOA, Addis Ababa, Ethiopia.

2. Asress Wolde Giorgis (1995). Ethiopia: Greenhouse Gas Emissions and Sources. In: Interim Report on Climate Change Country Studies. (RamosMañé, C. and Benioff, R., eds).

3. Balesdent, J., Wagner, G.H. and Mariotti, A. (1988). Soil organic matter turnover in long-term field experiments as revealed by Carbon-13 natural abundance. Soil Sci. Soc. Am. J. 52:118-124. 
4. Berg, B. (2001). Litter decomposition and organic matter turnover in northern forest soils. For. Ecol. Manage. 133:13-22.

5. Bernhard-Reversat, F. (1987). Dynamics of litter and organic matter at the soil-litter interface in fastgrowing tree plantations on sandy ferrallitic soil (Congo). Acta Oecologia 14:179-195.

6. Bi, H., Turvey, N.D. and Heinrich, P. (1992). Rooting density and tree size of Pinus radiata (D. Don) in response to competition from Eucalyptus oblique (L'Herit). For. Eco. Manage. 49:31-42.

7. Chamshama, S.A.O. and Nduwayezu, J.B. (2003). Rehabilitation of Degraded Sub-humid Lands in Sub-Saharan Africa: A Synthesis. Background paper presented for VITRI/ETFREN/UFRO-SPDC workshop, Trees, Agro-forestry and climate change in dryland Africa (ACCDA), Hyytiälä, Finland, 29 June-4 July 2003.

8. Davis, M.R. and Condron, L.M. (2002). Impact of grassland afforestation on soil carbon in New Zealand: a review of paired-site studies. Aust. J. Soil Research 40:675-690.

9. Dawit Solomon, Fritzsche, F., Lehmann, J., Tekalign, Mamo and Zech, W. (2002). Soil organic matter dynamics in the subhumid agroecosystems of the Ethiopian highlands: Evidence from natural ${ }^{13} \mathrm{C}$ abundance and particle-size fractionation. Soil Sci. Soc. Am. J. 66:969-978.

10. Della Bruna, E., Borges, A.C., Fernandes, B., Barros, N.F. and Mucovej, R.M.C. (1991). Actividade da microbiota de solos adicionados de serapilheira de eucalipto e de nutrients. Revista Brasileira de Ciencia do Solo 15:15-20.

11. FAO (1998). World Reference Base for Soil Resources. World Soil Resources Reports 84. Food and Agricultural Organization of The United Nations, Rome, Italy.

12. Fisher, R.F. (1995). Amelioration of degraded rain forest soils by plantations of native trees. Soil Sci. Soc. Am. J. 59:544-549.

13. Garten, Jr.C.T. (2002). Soil carbon storage beneath recently established tree plantations in Tennessee and South Carolina, USA. Biomass and Bioenergy 23:93-102.

14. Gebrekidan Teklu (2003). Expanse of Plantation Forest in Ethiopia (An outcome of more than half a century's effort). MoA, NRM and RD, Addis Ababa.

15. Grove, T.S., O'Connell, A.M., Mendham, D.S., Barrow, N.J. and Rance, S.J. (2001). Sustaining the Productivity of Tree Crops on Agricultural Land in South-western Australia, Publication No.10/09. Rural Industries Research and Development Corporation (RIRDC), Canberra.

16. Hingston, F.J., O'Connell, A.M. and Grove, T.S. (1989). Nutrient cycling in Jarrah forest. In: The Jarrah Forest: A Complex Mediterranean
Ecosystem, pp. 155-177, (Dell, B., Havel, J.J. and Malajczuk, N., eds). Kluwer Academic, Dordrecht, The Netherlands.

17. Jobbagy, E.G. and Jackson, R.B. (2000). The vertical distribution of soil organic carbon and its relation to climate and vegetation. Ecol. Appl. 10:423-436.

18. Jonsson, K., Ståhl, L. and Högberg, P. (1996). Tree fallows: A comparison between five tropical species. Bio. Fertil Soils 23:50-56.

19. Kardell, L., Steen, E. and Fabiao, A. (1986). Eucalyptus in Portugal -a threat or a promise. Ambio. 15:713.

20. Kebede Seifu (1998). Estimating Land Cover/Land Use Changes in Munessa Forest Area Using Remote Sensing Techniques. MSc thesis Report No. 1998:32, Swedish University of Agricultural Sciences, Skinnskatteberg.

21. Lal, R. (2001). World cropland soils as a source or sink for atmospheric carbon. Adv. Agr. 71:145-191.

22. Lamb, D. (1998). Large-scale ecological restoration of degraded tropical forest lands: The potential role of timber plantations. Rest. Ecol. 6:271-279.

23. Lugo, A.E. (1990). The apparent paradox of reestablishing species richness on degraded lands with tree monocultures. For. Ecol. Manage. 99:9-19.

24. Malhi, Y., Baldocchi, D.D. and Jarvis, P.G. (1999). The carbon balance of tropical, temperate and boreal forests. Plant Cell Environ. 22:715-740.

25. Mendham, D.S., O'Connell, A.M. and Grove, T.S. (2002). Change in soil carbon after land clearing or afforestation in highly weathered lateritic and sandy soils of south-western Australia. Agri. Eco. Env. 95:143-156.

26. Montagnini, F. (2001). Strategies for the recovery of degraded ecosystems: experiences from Latin America. Interciencia 26:498-503.

27. Mulugeta Lemenih and Fisseha Itanna (2004). Soil carbon stocks under various vegetation types and its dynamics following deforestation and conversion to arable lands along an elevation gradient in southern Ethiopia. Geoderma 123:177-188.

28. Mulugeta Lemenih, Olsson, M. and Karltun, E. (2004). Comparison of soil attributes under Cupressus lusitanica and Eucalyptus saligna established on abandoned farmland compared to soils subject to continuous farming in Ethiopia. For. Ecol. and manage. 195:57-67

29. Parrotta, A. (1999). Productivity, nutrient cycling, and succession in single-and mixed-species plantations of Casuarina equisetifolia, Eucalyptus robusta, and Leucaena leucocephala in Puerto Rico. For. Ecol. Manage. 124:45-77.

30. Parrotta, J.A., Turnbull, W.J. and Jones, N. (1997). Catalysing native forest regeneration on 
degraded tropical lands. For. Ecol. Manage. 99:17.

31. Paul, K.I., Polglase, P.J. and Richards, P.G. (2003). Predicted change in soil carbon following afforestation or reforestation, and analysis of controlling factors by linking a $\mathrm{C}$ accounting model (CAMFor) to models of forest growth (3PG), litter decomposition (GENDEC) and soil C turnover (RothC). For. Ecol. Manage. 177:485501.

32. Paul, K.I., Polglase, P.J., Nyakuengama, J.G. and Khanna, P.K. (2002). Change in soil carbon following afforestation. For. Ecol. Manage. 168:241-257.

33. Perrow, M.R. and Davy, A.J. (eds) (2002). Handbook of Ecological Restoration, Vol. 1. Principles of Restoration. Cambridge University Press, Cambridge.

34. Polglase, P.J., Paul, K.I., Khanna, P.K., Nyakungana, J.G., O'Connell, A.M., Grove, T.S. and Battaglia, M. (2000). Change in Soil Carbon Following Afforestation or Reforestation: Review of Experimental Evidence and Development of a Conceptual Framework. NCAS Technical Report No. 20. Australian Greenhouse Office, Canberra, Australia, pp. 117. http://www.greenhouse.gov.au/ncas/files/publicati ons.html.

35. Post, M.W. and Kwon, C.K. (2000). Soil carbon sequestration and land-use change: processes and potential. Glo. Cha. Boil. 6:317-327.

36. Scott, A.N, Tate, R.K., Ford-Robertson, J., Giltrap, D.J. and Smith, C.T. (1999). Soil carbon storage in plantation forests and pastures: land-use change implications. Tellus 51B:326-335.

37. Silver, W.L., Ostertag, R. and Lugo, A.E. (2000). The potential for carbon sequestration through reforestation of abandoned tropical agricultural and pasture lands. Rest. Ecol. 8:394-407.

38. Smith, P., Powlson, D.S., Glendining, M.J. and Smith, J.U. (1997). Potential for carbon sequestration in European soils: preliminary estimates for five scenarios using results from long-term experiments. Glo. Cha. Biol. 3:67-79.

39. Soil Survey Staff (1999). Keys to Soil Taxonomy, $8^{\text {h }}$ ed. Pocahontas Press, Blacksburg, VA.

40. Sombroek, W.G., Nachtergaele, F.O. and Hebel, A. (1993). Amount, dynamics and sequestering of carbon in tropical and subtropical soils. Ambio. 22:417-426.

41. Teissen, H., Cuevas, E. and Chacon, P. (1994). The role of soil organic matter in sustaining soil fertility. Nature 371:783-785.

42. Trouve, C., Mariotti, A., Schwartz, D. and Guillet, B. (1994). Soil organic carbon dynamics under Eucalyptus and Pinus planted on savannas in the Congo. Soil Bio. Bioche. 26:287-295.

43. Turner, J. and Lambert, M. (2000). Change in organic carbon in forest plantation soils in eastern Australia. For. Ecol. Manage. 133:231-247.

44. Winjum, J.K. and Schroeder, P.E. (1997). Forest plantations of the world: their extent, ecological attributes, and carbon storage. Agri. For. Meteo. 84:153-167. 